\title{
Sosialisasi Penggunaan Pupuk bioorganik-fosfat Pada Tanaman Cabai Merah (Capsicum annum $\mathrm{L}$ )
}

\author{
Lolita Endang Susilowati*, Zaenal Arifin
}

Program Studi Ilmu Tanah, Fakulas Pertanian, Universitas Mataram, Mataram, Indonesia.

\section{Article history}

Received: 14-06-2020

Revised: 14-07-2020

Accepted: 15-07-2020

*Corresponding Author: Lolita Endang Susilowati Program Studi Ilmu Tanah, Fakulas Pertanian, Universitas Mataram, Mataram, Indonesia Email:

lolitaabas37@unram.ac.id
Abstract: Bioorganic-phosphate fertilizer is an organic fertilizer enriched with phosphate solubilizing rhizobacteria (PSR). The addition of PSR to organic fertilizers is intended to improve the quality of organic fertilizer. The purpose of this community service activity is to socialize the use of bioorganic-phosphate fertilizers on red chili plants for reducing the use of inorganic fertilizers. This service activity used a participatory approach. As a target farmer partner is the "Bahtera" farmer group in Narmada Village, Narmada District, West Lombok Regency. This activity began with establishing a joint agreement between the community service team and the target farmers through a group discussion (FGD). The next activity was an extension activity about "bioorganic-phosphate fertilizer, its role, and benefits". Next, Activity of demonstration plot of integrated fertilizing was made at the farmer land to show the difference in yield with/ without used the combination fertilizer of bioorganic-phosphate and inorganic fertilizer. The chili yields show that fertilizing of the combination of bioorganic-phosphate and $75 \%$ of the recommended fertilizer dosage is higher than the $100 \%$ of the recommended dose. These community service activities achieve a positive response from farmers. This socialization activity needs to be carried out in other locations so that more farmers applying a fertilization pattern by combining bioorganic-phosphate and inorganic fertilizers.

Keywords: bioorganic-phosphate fertilizer; red chili; phosphate solubilizing rhizobacteria

Abtrak: Pupuk bioorganik-fosfat adalah pupuk organik yang diperkaya dengan rhizobacteria pelarut fosfat (PSR). Penambahan PSR pada pupuk organik dimaksudkan untuk meningkatkan kualitas pupuk organik. Tujuan dari kegiatan pengabdian masyarakat ini adalah untuk mensosialisasikan penggunaan pupuk bioorganik-fosfat pada tanaman cabai merah untuk mengurangi penggunaan pupuk anorganik. Kegiatan layanan ini menggunakan pendekatan partisipatif. Sebagai mitra petani target adalah kelompok tani "Bahtera" di Desa Narmada, Distrik Narmada, Kabupaten Lombok Barat. Kegiatan ini dimulai dengan membangun kesepakatan bersama antara tim layanan masyarakat dan petani sasaran melalui diskusi kelompok (FGD). Kegiatan selanjutnya adalah kegiatan penyuluhan tentang "pupuk bioorganik-fosfat, perannya, dan manfaatnya". Selanjutnya, kegiatan demplot percontohan pemupukan terpadu dilakukan di lahan petani untuk menunjukkan perbedaan hasil dengan / tanpa menggunakan kombinasi pupuk bioorganik-fosfat dan pupuk anorganik. Hasil cabai menunjukkan bahwa pemupukan kombinasi bioorganik-fosfat dan $75 \%$ dari dosis pupuk yang direkomendasikan lebih tinggi dari $100 \%$ dari dosis yang direkomendasikan. kegiatan pengabdian masyarakat ini mendapat respons positif dari petani. Kegiatan 
sosialisasi ini perlu dilakukan di lokasi lain sehingga lebih banyak petani menerapkan pola pemupukan dengan menggabungkan pupuk bioorganik-fosfat dan anorganik.

Kata Kunci: pupuk bioorganik fosfat, cabai merah, rhizobacteri pelarut fosfat

\section{PENDAHULUAN}

Cabai tergolong sayuran yang memiliki banyak manfaat, dapat sebagai bumbu masak atau sebagai bahan baku berbagai industri makanan dan obat-obatan. Tanaman ini mengandung vitamin A, B-kompleks, seperti niacin, pyridoxine (vitamin B-6), riboflavin dan thiamin (vitamin B-1), dan C (asam askorbat) dan beberapa jenis mineral seperti kalium, mangan, zat besi, dan magnesium (Kemala, 2005 ). Zat antioksidan (vitamin A dan C) pada cabai membantu melindungi tubuh dari efek radikal bebas. Rasa pedas pada cabai disebabkan oleh adanya senyawa Capsaicin, yaitu zat aktif yang digunakan untuk membantu mengobati sakit ringan dan nyeri otot/sendi syaraf (Kehei et al. 2012). Cabai dengan kandungan gizi dan vitamin yang beragam serta senyawa organic lainnya yang bermanfaat bagi kesehatan maka buah cabai diperlukan oleh manusia tidak sekedar untuk membangun selera makan tetapi sebagai komponen rempah obat herbal. Ragam manfaat yang dimiliki oleh cabai membuat cabai merah semakin menarik untuk diusahakan.

Kebutuhan akan cabai terus meningkat sejalan dengan tingginya permintaan masyarakat. Disamping itu, pada musim tertentu cabai mempunyai harga jual yang sangat menguntungkan bagi petani. Dua kedaan ini cenderung menjadi faktor pendorong petani untuk mengembangkan budidaya cabai. Dalam proses budidaya, peningkatan produktuvitas tanaman dapat dilakukan secara agronomik yaitu melalui pemupukan (Rosadi, 2015). Di dalam melaksanakan pemupukan, kebanyakan petani masih memilih menggunakan pupuk anorganik dengan berbagai alasan, diantaranya segera terlihat pengaruh pemberian pupuk terhadap pertumbuhan dan hasil tanaman, mudah dalam pengangkutan, dan pupuk tersedia di pasar pertanian. Keengganan petani untuk mengaplikasikan pupuk organic karena (1) diperlukan dalam jumlah yang sangat banyak sehingga biaya pengangkutan dan aplikasinya sangat besar, dan (2) respon tanaman lambat. Mereka tidak menyadari bahwa akibat penggunaan pupuk anorganik yang berlangsung lebih dari 40 tahun telah mengakibatkan tanah menjadi sakit. Saat ini, kemampuan tanah dalam menopang pertumbuhan tanaman menjadi berkurang. Hal ini ditunjukkan dengan tidak adanya peningkatan hasil dan bahkan cenderung menurun sekalipun takaran pemberian pupuk ditingkatkan.

Strategi pemulihan tanah yang sakit dilakukan dengan memulihkan kandungan bahan organic tanah. Status kandungan bahan organic pada tanah yang sakit berada pada kisaran sangat rendah sd rendah, sementara pada tanah subur ada pada kisaran sedang sd tinggi (Gamliei et al., 2016). Salah satu cara untuk memulihkan kandungan bahan organic dalam tanah dilakukan dengan pemberian pupuk organik. Pemberian pupuk organic akan memulihkan agregasi tanah, meningkatkan daya ikat tanah terhadap unsur hara dan air yang diberikan ke dalam tanah, meningkatkan populasi dan keragaman mikrobia tanah yang bermanfaat bagi pertumbuhan tanaman (Chirinda et al., 2008). Akan tetapi, pemberian pupuk organic 2 sd 3 ton per ha tidak akan mencukupi kebutuhan hara yang diperlukan oleh tanaman, sehingga pemberian pupuk anorganik masih tetap diperlukan. Untuk itu, pola pemupukan yang direkomendasikan kepada petani adalah pola pemupukan terpadu antara pupuk organik-anorganik dengan komposisi sesuai dengan kebutuhan masing-masing jenis tanaman. 
Pupuk bioorganik adalah pupuk organic yang diperkaya dengan mikrobia yang memberikan manfaat bagi pertumbuhan tanaman. Salah satu kelompok mikrobia tersebut adalah bakteri pelarut fosfat (Arifin dan Susilowati, 2017). Bakteri ini mempunyai peran tripel yaitu (2) meningkatkan ketersediaan fosfat dalam tanah, sehingga kebutuhan tanaman akan fosfat dapat terpenuhi sekalipun dengan takaran pemberian pupuk P-anorganik kurang dari takaran rekomendasi. Peran keduanya adalah sebagai decomposer. Peran ketiga sebagai pengendali penyakit tanaman yang disebabkan oleh Schlorotium rolfsii dan yang terakhir sebagai pemacu pertumbuhan akar tanaman. Kegiatan pengabdian ini bertujuan untuk mensosialisasikan penggunaan pupuk bioorganic-fosfat kepada Kelompok Tani Bahtera, untuk mengurangi penggunaan pupuk P-anorganik pada pertanaman cabai merah dan melihat pengaruhnya terhadap produktivitas cabai.

\section{METODE}

Kegiatan pengabdian ini menggunakan pendekatan partisipasif dan sinergitas antara mitra kelompok tani dan tim pelaksana pengabdian. Kelompok mitra tidak saja sebagai obyek sasaran tetapi juga sebagai pelaku/pengkaji teknologi yang diintroduksi oleh tim pengabdian. Kesepakatan bersama dibangun antara kelompok mitra dan tim pengabdian mulai dari proses perencanaan kegiatan, pelaksanaan kegiatan sampai dengan tahap evaluasi kegiatan. Tim pelaksana pengabdian bertindak sebagai fasilitator sehingga kemandirian kelompok dalam menyelesaikan setiap aspek permasalahan menjadi suatu prioritas.

Implementasi kegiatan pengabdian dilakukan dengan tahapan sebagai berikut:

1. FGD bersama antara tim pelaksana kegiatan dan mitra dengan fokus diskusi tentang (i) hak dan kuwajiban dari masing-masing kelompok (tim pengabdian dan mitra); (ii) penetapan waktu pelaksanaan kegiatan; (iii) penetapan tempat pelaksanaan kegiatan.

2. Kegiatan penyuluhan tentang "pupuk bioroganik-fosfat peran dan fungsinya dalam pertumbuhan tanaman". Penyuluhan dilakuakan dengan metode ceramah, diskusi, tanya jawab, dan tukar pengalaman. Peserta penyuluhan adalah anggota kelompok petani mitra dan petani di sekitar kelompok mitra.

3. Pelaksanan demplot. Demplot dibuat di lahan Ka Kelompok tani seluas $\pm 600 \mathrm{~m}^{2}$. Demplot percobaan pemupukan dilaksanakan oleh petani didampingi oleh tim pelaksana pengabdian. Bahan dan alat yang diperlukan meliputi:

- Pupuk BioOrganik

- Benih Cabai Varietas Darmais F1

- Pupuk Ponska dan Urea

- Mulsa palstik

- Lahan penanaman ( jarak tanam $50 \mathrm{~cm}$ x $60 \mathrm{~cm}$ )

Perlakuan percobaan pada Demplot ditata dalam 3perlakuan yaitu

- Perlakuan $100 \%$ takaran pupuk anorganik yang direkomendasikan

- Perlakuan $75 \%$ takaran pupuk anorganik yang direkomendasikan plus pupuk kandang (1 ton per ha).

- Perlakuan $75 \%$ takaran pupuk anorganik yang direkomendasikan plus pupuk BioOrganik-Fosfat (5g/tan)

Teknik perawatan tanaman cabai dan teknik pemupukan mengikuti cara yang biasa dilakukan oleh petani. Sebagai pupuk dasar adalah pupuk bioorganic-P ditambah 30\% dari total pupuk 
anorganik takaran rekomendasi dan sisanya diaplikasikan sebagai pupuk susulan yang diberikan seminggu sekali dengan volume $250 \mathrm{ml} /$ tanaman, dan setelah masuk fase generative diberi 500 $\mathrm{ml} /$ tanaman. Sementara untuk perlakuan yang tidak menerapkan pupuk bioorganic-fosfat sebagai pupuk dasar adalah 30\% darei pupuk anorganik yang diaplikasikan. Takaran pupuk rekomendasi (100\%) untuk tanaman cabai adalah 350 Urea, $250 \mathrm{SP}-36,100 \mathrm{KCl}$.

\section{HASIL DAN PEMBAHASAN}

\section{Penyuluhan mengenai "pupuk bioorganic- , konsep pemupukan terpadu/berimbang”}

Penyuluhan ini bertujuan untuk memperkaya pengetahuan petani terkait dengan ragam jenis pupuk, pengertian pupuk bioorganik-P, keuntungan dari penggunaan pupuk BioOrganik $\mathrm{P}$, dan konsep pemupukan terpadu. Luaran yang diharapkan dari kegaiatan penyuluhan ini adalah (a) Petani dapat menjelaskan pengertian pupuk dan pemupukan; (b) Petani dapat menjelaskan pengertian pupuk BioOrganik-fosfat; (c) petani dapat menjelaskan keuntungan dari penggunaan pupuk BioOrganikfosfat; (d) petani dapat menjelaskan konsep pemupukan terpadu

Penyuluhan diawali dengan penyampaian materi oleh tim pelaksana pengabdian dilanjutkan dengan diskusi, tanya-jawab. Beberapa pertanyaan yang diajukan oleh peserta, sebagai berikut:

1. Apa bedanya pupuk organic dan pupuk bioOrganik-Fosfat, dan mana yang lebih baik untuk pertumbuhan tanaman.

2. Bagaimana pupuk bioOrganik- fosfat bisa mengurangi takaran pemberian pupuk buatan

3. Apakah diperpolehkan pupuk hayati itu pemberiannya lewat daun

4. Petani sering menyemprot pupuk lewat daun dicampur dengan pestisida, ini bagaimana menurut ibu apa dibolehkan.

5. Apa bedanya pupuk yang disemprotkann lewat daun dengan pupuk yang dikocorkan lewat tanah.

Sebagai respon balik atas pertanyaan peserta penyuluhan, narasumber memberikan jawaban sesuai dengan nomer urut pertanyaan sebagaiberikut:

1. Pupuk organic adalah Pupuk organik merupakan bahan yang berasal dari sisa-sisa tanaman, hewan, seperti pupuk kandang, kompos, pupuk hijau, jerami, dan bahan lain yang dapat berperan memperbaiki kesuburan tanah. Sedangkan bioOrganik merupakan pupuk kompos yang diperkaya dengan mikrobia tertentu dari aplikasi pupuk hayati .Penambahan pupuk hayati berperan dalam mempermudah penyediaan hara bagi tanaman karena mengandung beberapa mikroorganisme yang bermanfaat bagi tanaman, seperti bakteri pelarut fosfat, bakteri penambat $\mathrm{N}$-udara.

2. Pupuk organik memiliki kandungan hara yang lengkap. Bahkan di dalam pupuk organik juga terdapat senyawa-senyawa organik lain yang bermanfaat bagi tanaman, seperti asam humik, asam fulvat, dan senyawa-senyawa organik lain. Hanya saja kadar kandungan hara tersebut rendah. Untuk mencukupi hara bagi tanaman, pemberian pupuk organic harus dibarengi dengan pupuk buatan. Jumlah pupuk buatan yang diberikan bisa dikurangi karena pupuk organic itu sudah mengadung hara. Meskipun kandungan haranya rendah tetapi kandungan senyawa-senyawa organic di dalam kompos ini memiliki peranan yang lebih penting dari pada peranan hara saja. Misalnya, asam humik dan asam fulvat. Kedua asam ini memiliki peranan seperti hormon yang dapat merangsang pertumbuhan tanaman. Kompos diketahui dapat meningkatkan nilai KTK (kapasitas tukar kation) tanah. Artinya tanaman lebih mudah menyerap unsur hara. Tanah yang diberi kompos juga menjadi lebih gembur dan aerasi tanah menjadi lebih baik. Tanah yang diberi kompos lebih banyak menyimpan air dan tidak mudah kering. Jika diamati lebih jauh, aktivitas 
mikroba pada tanah yang diberi kompos lebih tinggi daripada tanah yang tidak diberi kompos. Mikroba-mikroba ini memiliki peranan dalam penyerapan unsur hara oleh tanaman. Singkat cerita, kompos dapat memperbaiki sifat kimia, sifat fisik, dan sifat biologi tanah.

3. Pupuk hayati diberikan lewat tanah tidak lewat daun. Pupuk hayati tidak mengandung N, P, dan K. Kandungan pupuk hayati adalah mikrooganisme yang memiliki peranan positif bagi tanaman. Kelompok mikroba yang sering digunakan adalah mikroba-mikroba yang menambat $\mathrm{N}$ dari udara, mikroba yang malarutkan hara (terutama $\mathrm{P}$ dan $\mathrm{K}$ ), mikroba-mikroba yang merangsang pertumbuhan tanaman.

4. Cara yang benar tidak boleh dicampur antara pupuk dan pestisida. Kalau pestisida yang tidak boleh dicampur itu dipaksa dicampur juga, hasilnya tidak sehebat pestisida asli sebelum dicampur. Daya bunuh masing-masing pestisida menurun, malahan bisa hilang sama sekali. Itu karena terjadi "reaksi" antar bahan aktif dari msing-masing pestisida, sampai terbentuk senyawaan baru yang tidak beracun lagi.

5. Pupuk yang diberikan lewat daun itu merupan pupuk yang mengandung unsur mikro, yang dikocorkan ke tanah mengandung unsur makro. Pemberian pupuk yang dikocor itu merupakan cara pemberian pupuk susulan, biasaya diberikan tanaman sayuran seperti cabai, tomat. Pemupukan susulan pada musim kemarau lebih efektif dengan cara pengocoran daripada cara ditabur, dan masa musim hujan pemupukan cara ditabur lebih baik. Pengocoran dilakukan dengan membuat lubang di sisi tanaman dengan jarak $15 \mathrm{~cm}$ dari batang tanaman.
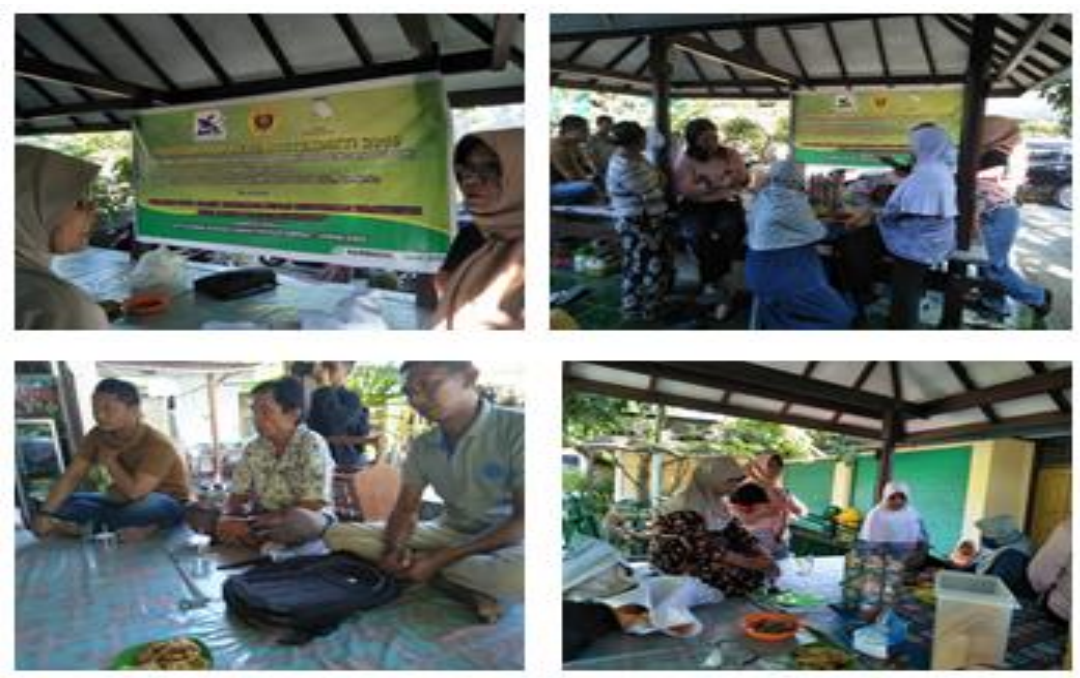

Gambar 1. Foto Penyuluhan Tentang Pupuk dan Pemupukan

Mengacu pada bentuk pertanyaan yang diajukan oleh petani, maka dapat disimpulkan bahwa petani telah memiliki pemahaman dasar tentang pupuk dan teknologi pemupukan. Antosias petani untuk meningkatkan pengetahuannya di bidang pupuk dan pemupukan terlihat tinggi. Bentuk pertanyaan yang diajukan oleh petani sangat rasional dan membutuhkan jawaban yang rinci dan mendalam. Peserta merasa puas atas jawaban yang diberikan oleh narasumber. Petani penyampaikan kegiatan penyuluhan ini memberikan manfaat besar, khususnya dalam meningkatkan pengetahuan petani dalam bidang pupuk dan pemupukan. Petani menjadi faham terkait dengan keuntungan dari pola pemupukan terpadu dalam mempertahankan kesuburan tanah dan meningkatkan hasil tanaman. Petani menguasai teknik aplikasi pola pemupukan terpadu pada tanaman cabai. Petani meminta 
penyuluhan semacam ini dapat diulang kembali di lain waktu untuk lebih memperkaya khasanah petani di bidang pupuk-pemupukan.

\section{Demplot pemupukan terpadu "pupuk bioorganic-fosfat dan anorganik"}

Demplot pemupukan dibuat untuk menunjukan secara langsung kepada petani mengenai keun-tungan dari penerapan pupukan terpadu "pupuk BioOrganik dan pupuk anorganik" dalam mempenga-ruhi hasil tanaman cabai. Gambar rangkaian kegiatan Demplot pemupukan terpadu ditunjukan dalam Gambar 2

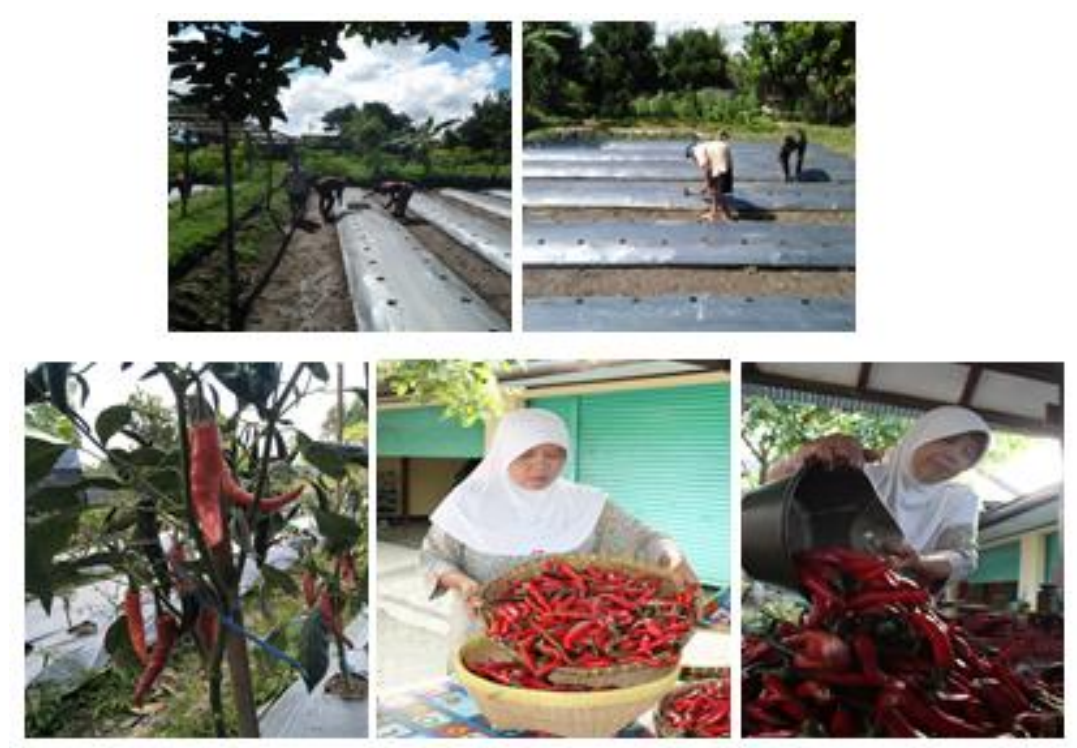

Gambar 2. Foto Kegiatan Demplot mulai dari Penanaman sd. Panen

Pupuk bırganık-tostat yang ditormulasıkan oleh Iim pelaksana pengabdian adalah pupuk organic yang proses pengomposannya menggunakan decomposer pupuk hayati $\mathrm{P}$ yang punya peran triple yaitu sebagai pupuk hayati $\mathrm{P}$, sebagai decomposer dan sebagai pengendali hayati untuk penyakit yang disebabkan oleh jamur Sclerotium rolfsii ( Arifin dan Susiowati, 2017). Adanya kandungan pupuk hayati $\mathrm{P}$ dalam kompos tersebut akan memacu proses transformasi senyawa $\mathrm{P}$ (anorganikorganik) dari bentuk tidak tersedia menjadi hara $\mathrm{P}$ yang tersedia bagi tanaman. Dengan demikian kebutuhan hara $\mathrm{P}$ pada tanaman cabai tercukupi secara optimal, yang selanjutnya berpengaruh terhadap proses fisiologi tanaman. Formulasi pupuk bioorganic-fosfat ini terus diujicoba pada berbagai tanaman pangan dan hortikultura, salah satunya pada tanaman cabai merah.

Hasil uji coba pemupukan terpadu dengan komposisi pupuk bioorganic-fosfat dan $75 \%$ takaran rekomendasi pupuk anorganik menghasilkan produksi cabai yang lebih tinggi dari pada hasil pada pemupukan $100 \%$ takaran rekomendasi. Semantara pola pemupukan terpadu dengan komposisi pupuk bioorganic-fosfat dan $75 \%$ takaran rekomendasi pupuk anorganik menghasilkan produksi cabai yang lebih rendah dari pada hasil pada pemupukan $100 \%$ takaran rekomendasi. 


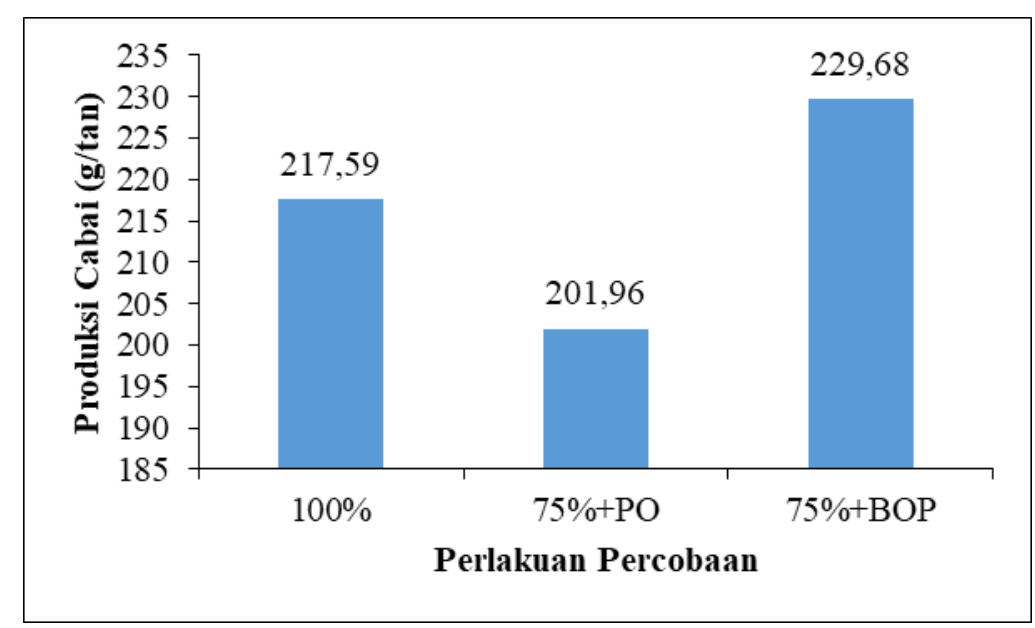

Gambar 3. Produksi Cabai pada 100\% takaran rekomendasi, pada 75 takaran rekomnedasi plus pupuk organic plus pupuk organik, pada 75\% takaran rekomnedasi plus pupuk bioorganic-P

Data produksi cabai pada Gambar 3 menunjukkan bahwa penggunaan pupuk bioorganikfosfat dapat mereduksi penggunaan pupuk anorganik sebesar $25 \%$ dengan perolehan hasil cabai lebih tinggi daripada penggunaan $100 \%$ takaran pupuk anorganik. Hasil ini mengindikasikan bahwa masukan kompos organic yang mengandung pupuk hayati P (bioorganic-fosfat) mampu menyediakan hara yang dibutuhkan tanaman cabai lebih tinggi dan lebih lengkap daripada yang disediakan oleh pupuk kimia dengan $100 \%$ takaran rekomendasi. Selanjutnya dapat ditunjukan bahwa aplikasi 1 ton pupuk kandang per ha tidak mampu mensubsitusi kebutuhan hara sebesar 25\% takaran pupuk anorganik. Karena itu hasil cabai pada pola pemupukan tersebut lebih rendah dibanding dengan pola pemupukan $100 \%$ takaran rekomendasi pupuk anorganik.

\section{KESIMPULAN DAN SARAN}

\section{Kesimpulan}

Kesimpulan yang didapatkan dari kegiatan pengabdian yaitu 1. Terjadi pola kemitraan yang sinergis antara tim dengan petani mitra, 2. Keingintahuan petani dalam ilmu pupuk dan pemupukan cukup tinggi sebagaimana ditunjukan dengan bentuk pertanyaan yang diajukan oleh petani peserta penyuluhan, 3. Melalui kegiatan Demplot petani mitra dapat melihat secara langsung mengenai kemampuan pupuk bioorganic-fosfat dalam mempengaruhi hasil tanaman, 4. Pupuk bioorganic-fosfat dapat mengurangi penggunaan pupuk anorganik sebesar 25\% dari takaran rekomendasi pupuk anorganik dengan hasil yang lebih tinggi dibanding dengan $100 \%$ takaran rekomendasi pupuk anorganik.

\section{Saran}

Sosialisasi penggunaan pupuk bioorganic-fosfat perlu diperluas wilayah sasarannya. Hal ini dimaksudkan untuk memantapkan pemanfaatan pupuk bioorganic-fosfat sebagai alternative teknologi guna mengurangi penggunaan pupuk anorrganik dan memelihara kesuburan tanah secara berkelanjutan 


\section{Ucapan Terima Kasih}

Tim pengabdi mengucapkan terima kasih kepada Kemenristekdikti yang telah memberi dukungan financial terhadap kegiatan ini melalui skim PKM Mono Tahun Anggaran Tahun 2019.

\section{DAFTAR PUSTAKA}

Kemala S. 2005. Laporan Proyek/Bagian Proyek Pengkajian Teknologi Pertanian Partisipatif/ PAATP Balai Penelitian Tanaman Rempah dan Obat Badan Penelitian dan Pengembangan Departemen Pertanian. Jakarta

Arifin,Z dan L.E. Susilowati. 2017. Formulasi konsorsium BPF-indigenos sebagai agen pupuk hayati $\mathrm{P}$ dan efikasinya dalam meningkatkan p-tersedia, serapan $\mathrm{p}$, pertumbuhan dan hasil tanaman kedelai. Laporan Penelitian Terapan Proyek Multitahun Kemenristtekdikti. LPPM Unram Mataram

Kehie, M., Kumaria, S., and Tandon, P. 2012. Osmotic Stress Induced Capsaicin Production in Suspension Cultures of Capsicum chinense Jacq.cv. Naga King Chili. Acta Physiol Plant, $34(2)$.

Rosadi, A. Husni Y. 2015. Kebijakan Pemupukan Berimbang untuk Meningkatkan Ketersediaan Pangan Nasional. J. PANGAN, Vol. 24 No. 1 Maret 2015: 1-14

Gamliel, A. dan van Bruggen, A. H. C. (2016). Maintaining Soil Health for Crop Production in Organic Greenhouses. Scientia Horticulturae 20:8 (2016) 120-130.

Chirinda, N;, Olesen, J.E; and Porter, J.R. 2008. Effects of organic matter input on soil microbial properties and crop yields in conventional and organic cropping systems. Th 16 IFOAM Organic World Congress, Modena, Italy, June 16-20, 2008. http://orgprints.org/view/projects/conference.html. 